\title{
The coprophilous fungus succession: a model system - abstract
}

\author{
John Webster \\ Department of Biological Sciences, University of Exeter, Exeter EX4 4PS, U.K.
}

Coprophilous fungi form an easily recognised ecological group adapted to severe disturbance. They survive as spores on herbage and are ingested, chewed, subjected to digestion, exposed to competition within the gut, egested and then suffer further competition and environmental variation. Studying the ecology of fungi on rabbit dung has several advantages, both for research and teaching. These include ready availability, ease of replication, simple techniques for varying the environment and levels of competition, and the possibility of adding spores to sterilised food. This is illustrated by studies on three aspects of the ecology of coprophilous fungi.

\section{The effects of water availability on fruit-body succession}

The importance of water supply (as determined by rainfall totals during the period of field incubation) on the species richness of the fungi which fruited on dung was shown by Yocom \& Wicklow (1980), who made observations on dung from laboratory-fed rabbits, placed in litter bags on the soil at various sand dune sites chosen to create different micro-environments, and left for different periods in the field before incubation in the laboratory. A different approach was adopted by Kuthubutheen \& Webster (1986a,b), who followed the fruiting of fungi on pellets collected in the field and incubated under different water regimes. They revealed dependence of Pilobolus and most Ascomycetes on freely-available water for continued fruiting. This was in marked contrast to the fruiting pattern of the synnematal hyphomycetes Stilbella, Onychophora and Doratomyces, which fruited better when provided with drier conditions. Water supply and competition had interactive effects on fruiting. In the absence of competitors, Pilobolus was able to fruit at lower relative humidities than when other fungal competitors were present.

\section{Interspecific antagonism}

Interspecific antagonism (interference competition) also affects fruiting and mycelial growth. For example, the production of a diffusible antibiotic by Stilbella erythrocephala (Ditm.) Lindau limits mycelial growth of many other coprophilous fungi. On dung, the fruiting of Pilobolus and Ascobolus was also depressed in the presence of Stilbella (Singh \& Webster 1973). Also, hyphal interference, a form of contact inhibition, of Coprinus heptemerus M. Lange \& A. H. Smith on the mycelium of Ascobolus inhibits fruiting of the latter on dung (Ikediugwu \& Webster 1970). 


\section{Synergism}

Cain \& Weresub (1957) showed that Viennotidia fimicola (Marchal) Cannon \& Hawks, is stimulated to form perithecia in culture by a contaminant, Eurotium repens de Bary. Fruiting is also stimulated in a range of coprophilous fungi and was most pronounced in the presence of coprophilous Ascomycetes, but not Zygomycetes and Basidiomycetes (Follett \& Webster, unpublished). There is now evidence of a diffusible metabolite produced by certain Ascomycetes, notably Ryparobius, which appears to be essential for complete perithecium development by Viennotidia (Follett \& Webster, unpublished).

\section{References}

Cain, R. F. \& Weresub, L. 1957. Studies of coprophilous ascomycetes V. Sphaeronaemella fimicola. Canadian Journal of Botany 35, 119-131.

Ikediugwu, F. E. O. \& Webster, J. 1970. Hyphal interference in a range of coprophilous fungi. Transactions of the British Mycological Society 54, 205-210.

Kuthubutheen, A. J. \& Webster, J. 1986a. Water availability and the coprophilous fungus succession. Transactions of the British Mycological Society 86, 63-76.

- \& 1986b. Effects of water availability on germination, growth and sporulation of coprophilous fungi. Transactions of the British Mycological Society 86, 77-91.

Singh, N. \& Webster, J. 1973. Antagonism between Stilbella erythrocephala and other coprophilous fungi. Transactions of the British Mycological Society 61, 487-495.

Yocom, D. H. \& Wicklow, D. T. 1980. Community differentiation along a dune succession: an experimental approach with coprophilous fungi. Ecology 61, 868-880. 